\title{
Comparison of global-warming potential impact of food waste fermentation to landfill disposal
}

\author{
Noor Intan Shafinas Muhammad ${ }^{1,2} \cdot$ Kurt A. Rosentrater $^{1}$
}

Received: 23 October 2019 / Accepted: 11 January 2020 / Published online: 23 January 2020

(c) Springer Nature Switzerland AG 2020

\begin{abstract}
Food waste (FW) has been identified as a critical global issue. The generation of $\mathrm{FW}$ is challenging to control because it is driven by various factors. Landfills, the most common final destinations for FW, are often associated with negative economic and environmental impact. Most previous studies have found that FW could also contribute to global warming due to GHG emission from decomposition of organic waste, so it is important to divert FW from landfills and find a better option such as using it to produce other value-added products. Depending on the particular FW composition, such waste has potential to be used in fermentation technology, so the primary objective of this study is to compare the global-warming potential (GWP) impact of FW fermentation and landfill disposal methods. Life-cycle assessment (LCA) was conducted to determine the effect on environmental of four scenarios: (i) FW fermentation without enzymes and a 2-step distillation system, (ii) FW fermentation without enzymes and a membrane distillation separation process, (iii) FW fermentation integrated with combined heat power (CHP), and (iv) FW in landfills. As expected, all FW fermentation options produced lower GWP impact values than a landfilling method. From the overall fermentation process, the lowest total GWP value was $164.1 \mathrm{~kg} \mathrm{CO}$-eq/1 Mg of FW for the second scenario. Membrane distillation is an environmentally sound process, and suggesting that FW can be utilized to produce value-added products in fermentation while minimizing the environmental burden.
\end{abstract}

Keywords Food waste · Fermentation · GWP

\section{Introduction}

The increasing volume of food waste (FW) every year is one of the most critical waste management issues. Gustavsson, et al. [1] reported that about 1.3 billion tonnes of FW is produced yearly, equivalent to one-third of the world's food produced in any of the food supply chain stages. The increasing use of FW generation is driven by the modernization of the food system, and by cultural socio-demographic human behavior and attitudes, and safety policy [2]. There are, however, negative economic, environment, social, and health impacts associated with
FW if it is not managed effectively. For example, in 2015, FW economic losses accounted for approximately $\$ 940$ billion in the UK and $\$ 1500$ to $\$ 1100$ per capita on average in the USA $[3,4]$.

There are several disposal methods for FW, such as composting, anaerobic digestion (AD), incineration, landfills, and fermentation. While composting and anaerobic digestion is a mature technology that can produce bio-fertilizer and methane as primary products, this method is often deemed unfavorable because of its requirements of longer process time, higher cost of operation, ease spreading pathogens, and emission

$\triangle$ Kurt A. Rosentrater, karosent@iastate.edu | ${ }^{1}$ Agricultural and Biosystems Engineering Department, lowa State University, Elings Hall, Ames, IA 50011, USA. ${ }^{2}$ Faculty of Engineering Technology, Universiti Malaysia Pahang, Lebuhraya Tun Razak, 26300 Kuantan, Pahang, Malaysia. 
of volatile organic compounds (VOC) [5, 6]. Incineration technology involves combustion and conversion of chemical energy into heat and electrical power, and even though it could reduce the FW by up to $80-85 \%$, it has still not received full support from some countries, mainly because toxic air emission exhaust from incineration is harmful to the environment. In addition, due to the high moisture content of FW, its combustion efficiency will be affected and perhaps economically infeasible [7]. Landfill is a traditional method in waste management, and as reported by the EPA [8], in the year 2015 at least $76.1 \%$ of FW was sent to landfills. This disposal option will require large land space and high cost, and it negatively impacts the environment $[6,9]$. According to Gao et al. [10], landfill impact on climate change is ten times greater than that of anaerobic digestion, incineration, and composting, so this method will significantly add to global environmental problems.

Alternatively, FW can be used as a fermentation feedstock because it contains valuable resources for producing other valuable products. For example, glucose is found to be a significant component in $\mathrm{FW}$, and yeast could convert glucose into ethanol under anaerobic conditions in a controlled environment. Study done by Muhammad [11] reveals that FW has potential for use in a fermentable process without enzymes in producing value-added products. Additionally, this study will present a comprehensive comparison on the economic impact of a FW fermentation plant for different scenarios. However, to determine feasibility of such new technology for commercialization, both economic and environmental perspectives should be considered.

Therefore, the focus of this study was to make a comparative assessment of the global-warming potential (GWP) of FW fermentation and landfilling disposal methods.
Life-cycle assessment (LCA) was conducted to estimate GWP for each process in terms of $\mathrm{kg} \mathrm{CO}_{2}$ equivalents.

\section{Methodology}

\subsection{Life-cycle assessment (LCA)}

LCA is an essential tool for determining the environmental burden associated with FW fermentation processes, and concepts and life-cycle stages should be considered, as shown in Fig. 1.

The LCA framework used in this study complies with ISO 14040: 2006. This framework includes the goal and scope of $L C A$, life-cycle inventory analysis $(\mathrm{LCl})$, and lifecycle impact assessment (LCIA) and interpretation [12]. Greenhouse emission release from the process should be assessed using the GWP in 100 years. This method, used in various studies to address global-warming impact, includes three main commonly used GHGs: carbon dioxide $\left(\mathrm{CO}_{2}\right)$, methane $\left(\mathrm{CH}_{4}\right)$, and nitrous oxide $\left(\mathrm{N}_{2} \mathrm{O}\right)$ that trap heat like a blanket and insulate the earth, thereby increasing global temperature and consequently leading to various catastrophic impacts on the ecosystem [13]. The GWP values relative to $\mathrm{kg} \mathrm{CO}_{2}$-eq/1 $\mathrm{Mg}$ of $\mathrm{FW}$ listed in Table 1 will be used to modify the GHG value through multiplication with a conversion factor taken from the Intergovernmental Panel on Climate Change (IPCC) Fifth Assessment Report (AR5).

In this study, energy demand for a process plant is counted as an input stream for heating and steam production, assuming it is generated by natural gas fuel with $80 \%$ thermal efficiency. Emission generation will be estimated using a conversion factor of $66.33 \mathrm{~kg} \mathrm{CO}_{2}$-eq per $1 \mathrm{mmBTU}$ of steam or heat used in the plant [15].
Fig. 1 Life-cycle stages for the project

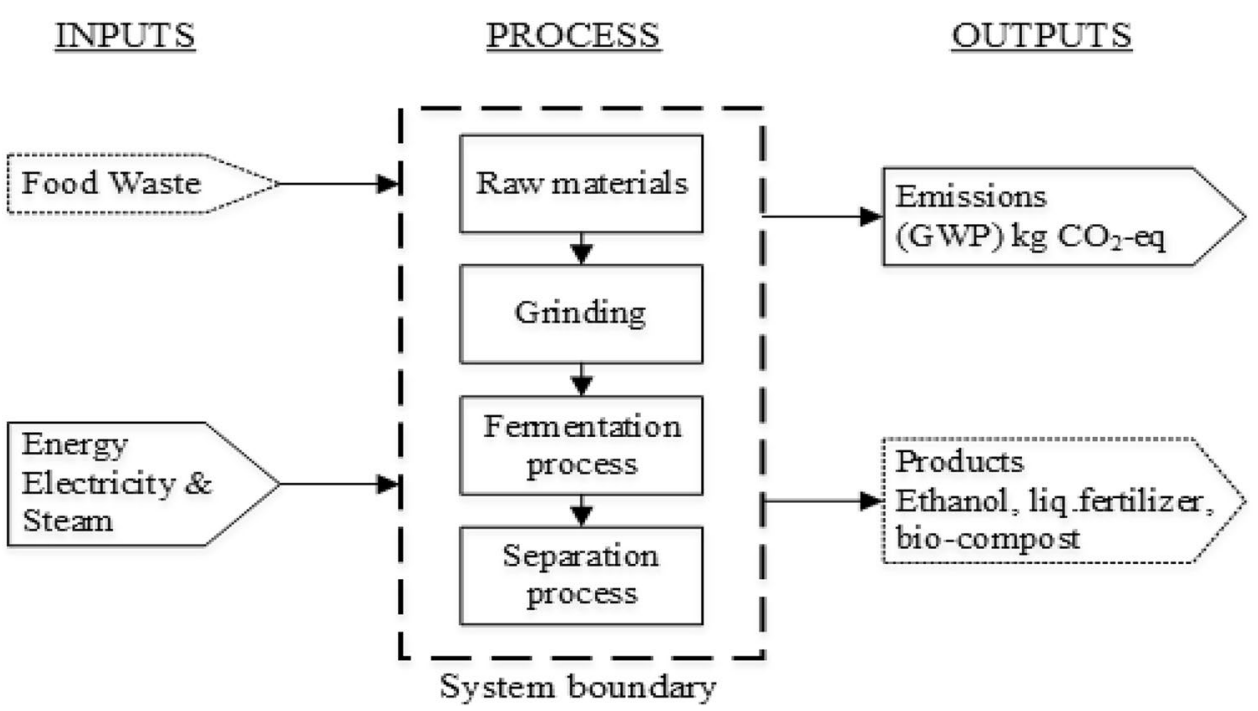


Table 1 Global-warming potential (GWP) values relative to $\mathrm{CO}_{2}[14]$

\begin{tabular}{ll}
\hline $\begin{array}{l}\text { Industrial designation or com- Chemical formula } \\
\text { mon name }\end{array}$ & $\begin{array}{l}\text { Approximately lifetime } \\
\text { (year) }\end{array}$
\end{tabular}

GWP values for 100-year time horizon ( $\mathrm{kg} \mathrm{CO}_{2}$-eq)

\begin{tabular}{lllr}
\hline Carbon dioxide & $\mathrm{CO}_{2}$ & Variable & 1 \\
Methane & $\mathrm{CH}_{4}$ & 12 & 28 \\
Nitrous oxide & $\mathrm{N}_{2} \mathrm{O}$ & 114 & 265
\end{tabular}

Table 2 Greenhouse gas emissions of the selected source of electricity supply technology [16]

\begin{tabular}{ll}
\hline Source of electric power generation facilities & $\begin{array}{l}\mathrm{GWP} \text { value (g } \\
\mathrm{CO}_{2} \text {-eq/kWh) }\end{array}$ \\
\hline Coal & 820 \\
Natural gas & 490 \\
Biomass co-firing & 740 \\
Geothermal & 38 \\
Hydropower & 24 \\
Nuclear & 12 \\
Concentrated solar power & 27 \\
Solar PV-rooftop & 41 \\
Wind-offshore & 12 \\
\hline
\end{tabular}

Since emission from electricity will also be included in this study, a few different electric power generation facilities are identified as possible electricity sources. Table 2 shows the conversion factors for an electric supply, and their median value is used for estimating such emission.

For landfills, the number of emissions is estimated using The Landfill Gas Emission Model (LandGEM), version v3.02 $[17,18]$. The model for $\mathrm{CH}_{4}$ generation is given by Eq. 1 .

$A=\left[\sum_{x=S}^{T-1}\left\{W_{x} L_{x}^{\prime}\left(e^{-k(T-x-1)}-e^{-k(T-x)}\right)\right\}\right]$

where $A=\mathrm{CH}_{4}$ generation (Mg/year), $x=$ year in which FW was disposed, $S=$ inventory year for the year which emissions are calculated (2017), $T=$ inventory year for the year which emission are calculated (2018), $W_{x}=$ quantity of FW disposed at the landfill $(\mathrm{Mg})$ for 1 year, $L^{\prime}=\mathrm{CH}_{4}$ generation potential $\left(\mathrm{MgCH}_{4} / \mathrm{Mg} \mathrm{FW}\right)=\mathrm{MCF} \times \mathrm{DOC} \times \mathrm{DOC}_{F} \times \mathrm{F} \times$ $16 / 12=L_{o} \times 16 / 0.02367 \times 10^{-6}, L_{o}=\mathrm{CH}_{4}$ generation potential $\left(\mathrm{m}^{3} \mathrm{CH}_{4} / \mathrm{Mg} \mathrm{FW}\right)=493 \times \mathrm{DOC}, \mathrm{MCF}=\mathrm{CH}_{4}$ correction factor (fraction), assumed to be 1 for managed landfills, $\mathrm{DOC}=$ degradable organic carbon ( $\mathrm{MgC}$ in FW/Mg FW), $\mathrm{DOC}_{F}=$ fraction of DOC decomposed, assumed to be 0.5 , $F=$ fraction by volume of $\mathrm{CH}_{4}$ in landfill gas assumed to be $0.5, k=$ decay rate constant $\left(\right.$ year $\left.^{-1}\right)$.

For the amount of $\mathrm{CO}_{2}$ emission in the landfills, Eq. 2 will be used as follows;
$B=A \times\left(\frac{1-F}{F}+O X\right) \times \frac{44}{16}$

where $B=\mathrm{CO}_{2}$ generation (Mg/year), $A=\mathrm{CH}_{4}$ generation from Eq. 2 ( $\mathrm{Mg} \mathrm{CH} \mathrm{CH}_{4}$ year), $F=$ fraction by volume of $\mathrm{CH}_{4}$ in landfill gas assumed to be $0.5, \mathrm{OX}=$ soil oxidation fraction, assumed to be $0.1,44=$ molecular weight of $\mathrm{CO}_{2}(\mathrm{~kg} /$ $\mathrm{kg} \mathrm{mol}), 16=$ molecular weight of $\mathrm{CH}_{4}(\mathrm{~kg} / \mathrm{kg} \mathrm{mol})$

\subsection{Goal and scope}

The goal of this study is to evaluate the GWP for FW fermentation under assumptions of three different scenarios and compare the results with those of landfilling methods, to provide information on this process to investors or decision makers for future use. Scenarios (i) to (iii) will be modeled using SuperPro Designer V9.0 to calculate the overall mass and energy balance including the emission release from the system. However, for scenario (iv), Eqs. 1 and 2 were used to estimate the total GWP impact from landfilling method. The scenarios are listed below:

Scenario (i) FW fermentation without enzymes and 2-step distillation system

Scenario (ii) FW fermentation without enzymes and membrane distillation

Scenario (iii) FW fermentation integrated with combined heat power (CHP)

Scenario (iv) FW in the landfill

\subsection{Functional unit}

The functional unit in this study is the feedstock flow to the system boundary, and for calculation, $1 \mathrm{Mg}$ of FW will be considered as a primary reference for each scenario.

\subsection{System boundary}

In this study, the gate-to-gate life-cycle inventory will be considered. For each of the scenarios, system boundary is covered from the feedstock stream to its final product. The schematic flow for each scenario is shown in Figs. 2, 3,4 , and 5 . For scenario (i) to (iii), the system boundary is modeled with three main unit operations: size reduction, fermentation, and separation. For all three scenarios, 

scenario (i)
Fig. 2 System boundary of
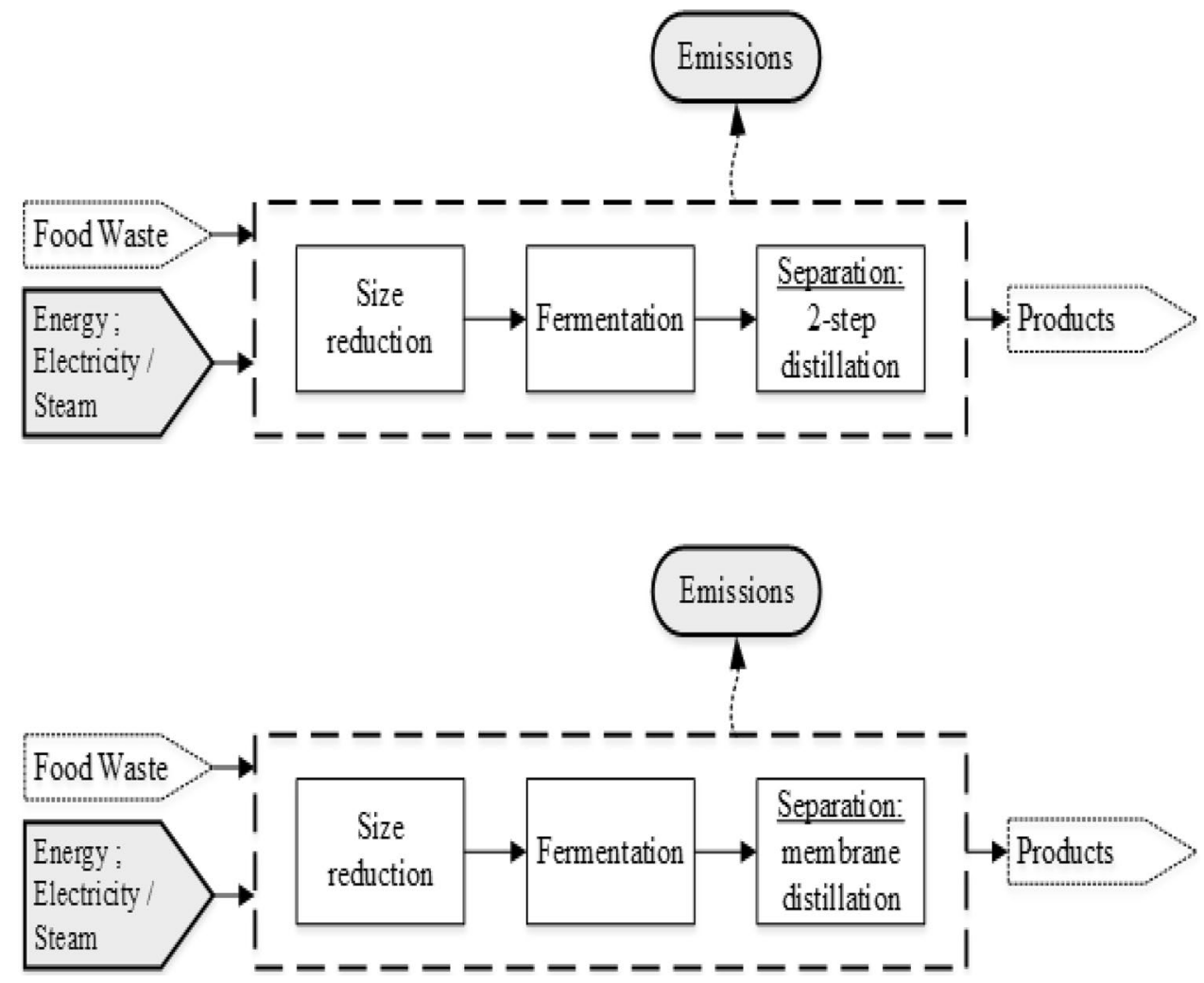

Fig. 3 System boundary of scenario (ii)

Fig. 4 System boundary of scenario (iii)

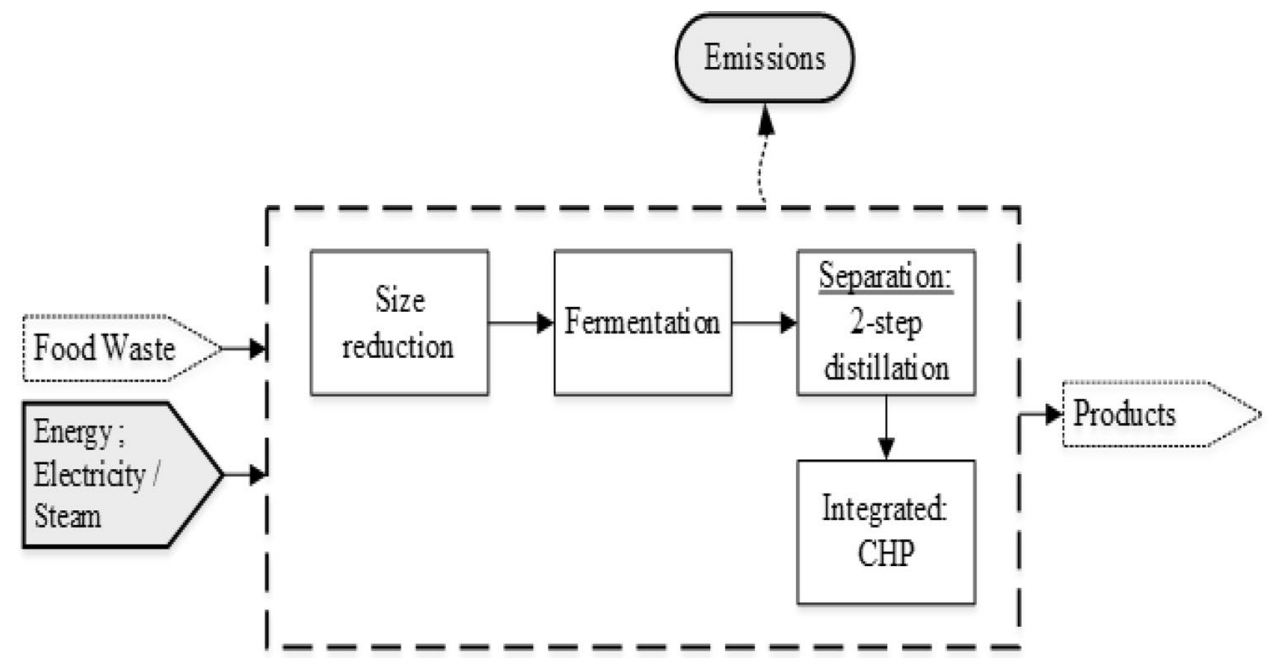

1 MG of FW will be simulated as a feedstock capacity. The FW size will be reduced to enhance the fermentation rate. A grinder was used as a unit operation at the beginning process. Anaerobic fermentation without enzymatic assistance by Saccharomyces cerevisiae with temperature $30^{\circ} \mathrm{C}$ was modeled in all scenarios. As for downstream processing, two types of separation were used: 2 -step distillation and membrane distillation. There are three main products anticipated from this process: ethanol, liquid fertilizer, and bio-compost or energy. In particular, the bio-compost will be burnt and converted into energy through combined heat and power (CHP) processes as shown in Fig. 4 to determine the effect of in site energy production by recycling solid waste stream.

In this study, the LCA scope is estimation of how many kgs of $\mathrm{CO}_{2}$-eq will be released to the atmosphere from each scenario. Limitations and assumptions are as follows: 


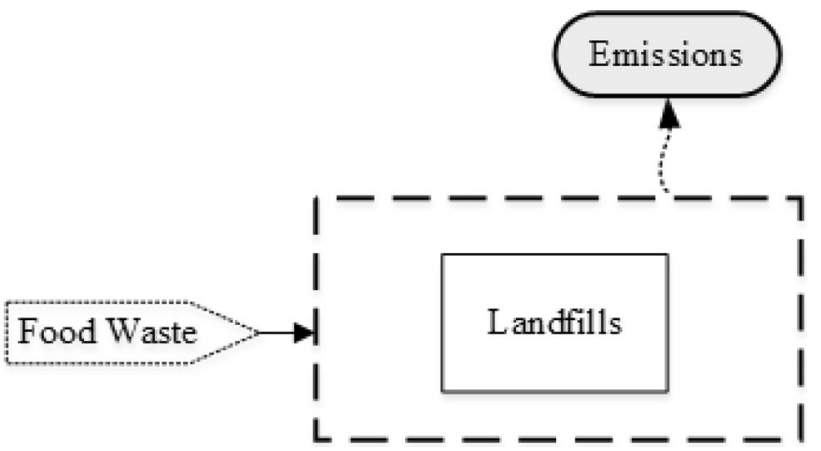

Fig. 5 System boundary of scenario (iv)

1. Transportation emission is not included because distance between the processing plant and collected areas is considered to be similar for all scenarios.

2. Equipment and chemical inputs for the fermentation process are not included.

3. Products and co-products will not be considered

4. GWP value for FW ahead of the system boundary will not be included, and it is assumed that such an amount will be the same for $1 \mathrm{Mg}$ of FW in all scenarios.

As mentioned above, Eq. 3 will be used to calculate the total GWP impact for the respective scenarios. Each of the criteria will be converted into $\mathrm{kg} \mathrm{CO}_{2}$ eq unit before total GWP will be estimated.

Total GWP impact $\left(\mathrm{kg} \mathrm{CO}_{2}\right.$ eq $)=$ Direct emissions $\left(\mathrm{CO}_{2} \& \mathrm{CH}_{4}\right)$

$\left(\mathrm{kg} \mathrm{CO}_{2}\right.$ eq $)+\sum$ energy generation $[$ steam $(\mathrm{mmBTU})$

+ electric power $(\mathrm{kWh})](\mathrm{kgCO}$ eq)

\section{Results and discussions}

\subsection{Life-cycle inventory}

Three scenarios were modeled using SuperPro designer V9.0 assuming $1 \mathrm{Mg}$ of FW as feedstock, with the processes requiring heat and electrical energy as inputs. From Muhammad [11], ethanol conversion from FW without enzymes is $2.2 \%(\mathrm{w} / \mathrm{w})$ on a wet basis, and even though this conversion rate is low compared to the yield found by Uncu and Cekmecelioglu [19], the economic impact is considerable. The FW composition used in this model is assumed to be $78 \%$ moisture content with $45 \%$ glucose, $19 \%$ starch, $5 \%$ fiber, and other trace elements. This assumption was taken as average values of FW composition from university dining hall from previous studies [11, 19-21]. The energy demand and emission emitted from the overall process were obtained from simulation.

\subsection{GWP impacts}

A summary of process energy input and estimated emission output is given in Table 3 for each scenario, and to estimate the GWP impact value, energy and emission impact will be included in the overall process. For scenarios (i)-(iii), these values are taken from the simulation model. While for scenario (iv), the value is predicted from the equation above. However, the GWP impact for electrical energy differs for different types of electricity sources. In this study, coal had a significantly higher impact on the environment followed by biomass co-firing and natural gas.

Figure 6 shows the overall value of GWP for each scenario, including direct emissions, emissions from steam generation, and then indirect emissions for various electricity generation. For the energy input, the GWP impact depends on the sources of electricity generation by using conversion factor as shown in Table 2 . Scenario D, representing the landfilling method, produces a higher GWP impact of $2555.0 \mathrm{~kg} \mathrm{CO}$-eq/1 Mg of FW. From previous studies, the GWP values from the landfilling method range from $1010 \mathrm{~kg} \mathrm{CO}_{2}$-eq to $2538 \mathrm{~kg} \mathrm{CO}_{2}$-eq per $\mathrm{FW}[5$, 9], depending on FW compositions, duration, and location. For scenarios (i), (ii), and (iii), while the GWP value also varies depending on the electric source, as a general assumption the average value reflects the environmental impact for all process plants. Scenario (ii) produced the smallest total value of GWP, followed by scenario (i) and
Table 3 Summary of process energy inputs and emission outputs

\begin{tabular}{|c|c|c|c|c|}
\hline & \multicolumn{2}{|l|}{ Energy } & \multicolumn{2}{|c|}{ Direct Emissions } \\
\hline & $\begin{array}{l}\text { Steam inputs } \\
(\mathrm{mmBTU} / \mathrm{Mg} \mathrm{FW})\end{array}$ & $\begin{array}{l}\text { Electric power inputs } \\
\text { (kWh/Mg FW) }\end{array}$ & $\begin{array}{l}\mathrm{CO}_{2} \\
(\mathrm{~kg} / \mathrm{Mg} \mathrm{FW})\end{array}$ & $\begin{array}{l}\mathrm{CH}_{4} \\
(\mathrm{~kg} / \mathrm{Mg} \mathrm{FW})\end{array}$ \\
\hline Scenario (i) & 0.949 & 411.1 & 59.7 & 0 \\
\hline Scenario (ii) & 0.03 & 418.3 & 59.7 & 0 \\
\hline Scenario (iii) & 0.9481 & 193 & 244.3 & 0 \\
\hline Scenario (iv) & 0 & 0 & 2519.8 & 35.2 \\
\hline
\end{tabular}




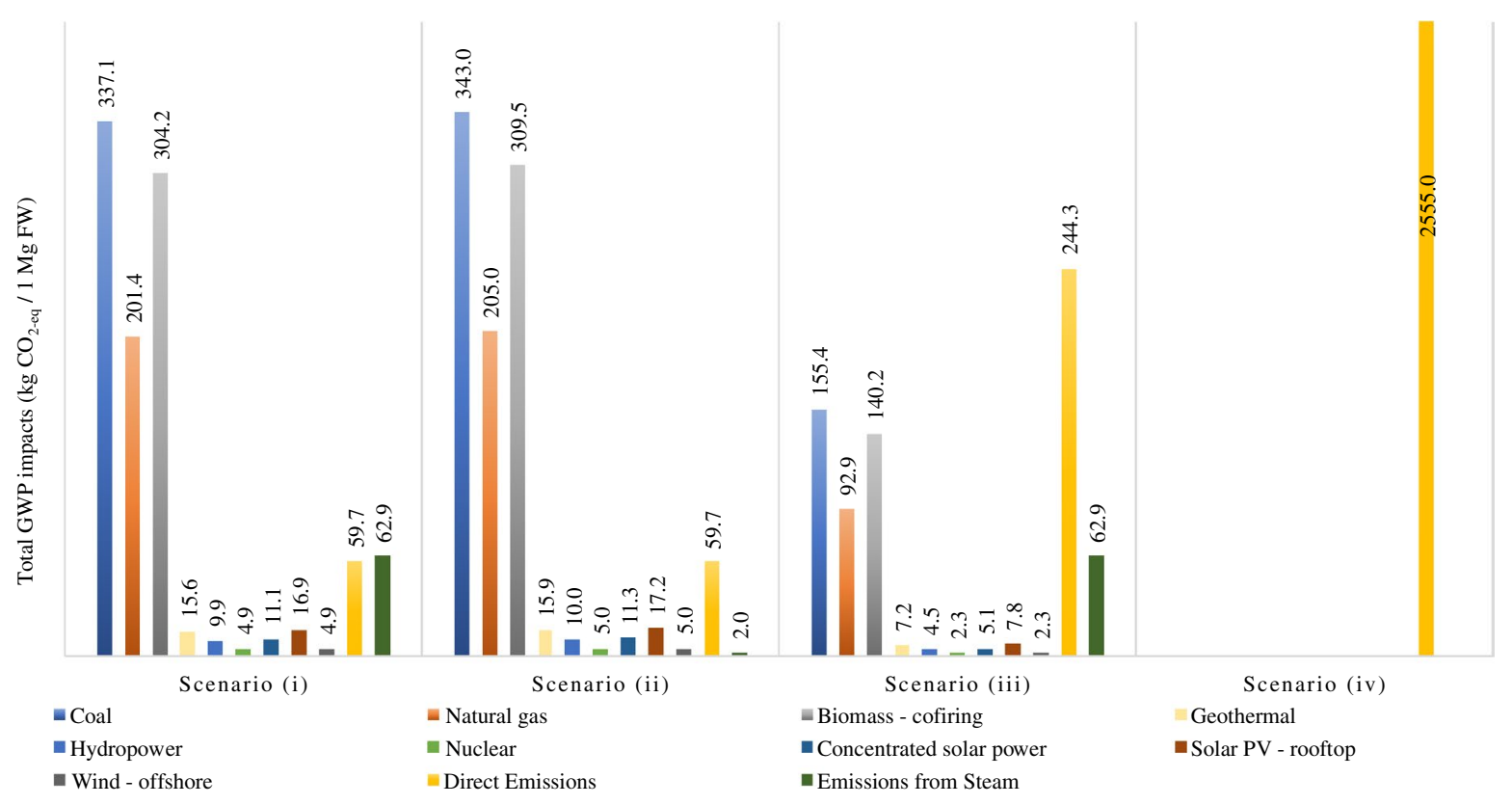

Fig. 6 Overall GWP impact among all scenarios

(iii), viz., $164.1 \mathrm{~kg} \mathrm{CO}$-eq, $223.3 \mathrm{~kg} \mathrm{CO}$-eq, and $353.6 \mathrm{~kg}$ $\mathrm{CO}_{2}$-eq per $1 \mathrm{Mg}$ of $\mathrm{FW}$, respectively.

Scenario (iii) has the highest amount of emission due to the combustion process and dryer used in a CHP system, and the burning associated with the solid waste process will add more $\mathrm{CO}_{2}$ emission from fermentation. The solid waste drying process also contributes to the higher amount of GWP because of its higher electric power requirement.

Scenario (ii) has a lower GWP impact than scenario (i) because of the small amount of steam requirement in the processing plant. A study conducted by Muhammad [11] had discussed the distillation column is an energy intensive process compared to membrane distillation. In a distillation column, the process of separating ethanol from the fermentation broth largely depends on using more heating elements. In contrast, membrane distillation is driven by pressure differences and membrane selectivity, so both the energy input and the GWP impact are less in membrane distillation.

\section{Conclusions}

This study presents a comprehensive comparison of global-warming potential impact for four different FW disposal option processes. As expected, landfilling had a considerably higher GWP impact than the fermentation processes. Results showed that FW fermentation with membrane separation process had the least GWP impact given by $164.1 \mathrm{~kg} \mathrm{CO}$-eq/1 Mg of FW followed by 2-step distillation and CHP depending upon assumptions. The results for all FW fermentation methods show that the environmental impact is directly proportional to energy requirements in the conversion process.

This finding reveals that utilizing FW in the fermentation process can be a practical and sustainable way to manage FW relatively than sending it to landfills. This is one of the promising options to convert waste into valuable products while minimizing the environmental burden.

\section{Compliance with ethical standards}

Conflict of interest The authors declare that they have no conflict of interests.

\section{References}

1. Gustavsson J, Cederberg C, Sonesson U, van Otterdijk R, Meybeck A (2011) Global food losses and food waste: extent, causes and prevention. Int Congr Save Food. https://doi.org/10.1098/ rstb.2010.0126

2. Thyberg KL, Tonjes DJ (2016) Drivers of food waste and their implications for sustainable policy development. Resour Conserv Recycl 106:110-123. https://doi.org/10.1016/J.RESCO NREC.2015.11.016

3. FAO (2015) Food wastage footprint \& climate change. FAO, Rome

4. Lipinski B, Clowes A, Goodwin L, Hanson C, Swannell R, Mitchell $P$ (2017) SDG target 12.3 on food loss and waste: 2017 progress report an annual update on behalf of champions 12.3. https ://champions123.org/wp-content/uploads/2017/09/champ 
ions-123-sdg-target-123-2017-progress-report.pdf. Accessed 1 Aug 2019

5. Parthiba Karthikeyan O, Trably E, Mehariya S, Bernet N, Wong JWC, Carrere H (2018) Pretreatment of food waste for methane and hydrogen recovery: a review. Bioresour Technol 249:10251039. https://doi.org/10.1016/J.BIORTECH.2017.09.105

6. Xu F, Li Y, Ge X, Yang L, Li Y (2018) Anaerobic digestion of food waste-challenges and opportunities. Bioresour Technol 247:1047-1058. https://doi.org/10.1016/J.BIORT ECH.2017.09.020

7. Pham TPT, Kaushik R, Parshetti GK, Mahmood R, Balasubramanian $\mathrm{R}$ (2015) Food waste-to-energy conversion technologies: current status and future directions. Waste Manag 38:399-408. https://doi.org/10.1016/J.WASMAN.2014.12.004

8. EPA (2018) Advancing sustainable materials management: 2015 fact sheet assessing trends in material generation, recycling, composting, combustion with energy recovery and landfilling in the United States. EPA, Washington

9. Kim M-H, Kim J-W (2010) Comparison through a LCA evaluation analysis of food waste disposal options from the perspective of global warming and resource recovery. Sci Total Environ 408:3998-4006. https://doi.org/10.1016/J.SCITO TENV.2010.04.049

10. Gao A, Tian Z, Wang Z, Wennersten R, Sun Q (2017) Comparison between the technologies for food waste treatment. Energy Proc 105:3915-3921. https://doi.org/10.1016/J.EGYPR O.2017.03.811

11. Muhammad NIS (2019) Comparative assessment of the economic and environmental impacts of food waste fermentation on value-added products. Dissertation, lowa State University

12. ISO (2006) 14040: environmental management-life cycle assessment-principles and framework. ISO, London

13. Mendelsohn R, Prentice IC, Schmitz O, Stocker B, Buchkowski R, Dawson B (2016) The ecosystem impacts of severe warming. Am Econ Rev 5:612-614. https://doi.org/10.1257/aer.p20161104

14. Stoker T, Qin D, Plattner GK, Tignor M, Allen SK, Boschung J et al (2013) Climate change 2013: the physical science basis. Intergovernmental panel on climate change, working group I contribution to the IPCC fifth assessment report (AR5)
15. EPA (2018) Emission factors for greenhouse gas inventories. EPA. Available online: https://www.epa.gov/sites/production /files/2018-03/documents/emission-factors_mar_2018_0.pdf. Accessed 1 Aug 2019

16. Schlömer S, Bruckner T, Fulton L, Hertwich Austria E, McKinnon AU, Perczyk D et al (2014) III ANNEX technology-specific cost and performance parameters Editor: Lead Authors: Contributing Authors: to the fifth assessment report of the intergovernmental panel on climate change [Edenhofer technology-specific cost and performance parameters annex

17. EPA (2005) Landfill gas emissions model (LandGEM). EPA. Available online: https://www3.epa.gov/ttncatc1/dir1/landgemv302-guide.pdf. Accessed 1 Aug 2019

18. EPA (2010) Greenhouse gas emissions estimation methodologies for biogenic emissions from selected source categories. EPA. Available online: https://www.epa.gov/air-emissions-facto rs-and-quantification/greenhouse-gas-emissions-estimation -methodologies-biogenic. Accessed 1 Aug 2019

19. Uncu ON, Cekmecelioglu D (2011) Cost-effective approach to ethanol production and optimization by response surface methodology. Waste Manag 31:636-643. https://doi.org/10.1016/J. WASMAN.2010.12.007

20. Hafid HS, Nor'Aini AR, Mokhtar MN, Talib AT, Baharuddin AS, Umi Kalsom MS (2017) Over production of fermentable sugar for bioethanol production from carbohydrate-rich Malaysian food waste via sequential acid-enzymatic hydrolysis pretreatment. Waste Manag 67:95-105. https://doi.org/10.1016/J.WASMA N.2017.05.017

21. Vavouraki Al, Volioti V, Kornaros ME (2014) Optimization of thermo-chemical pretreatment and enzymatic hydrolysis of kitchen wastes. Waste Manag 34:167-173. https://doi. org/10.1016/j.wasman.2013.09.027

Publisher's Note Springer Nature remains neutral with regard to jurisdictional claims in published maps and institutional affiliations. 